\title{
New long-tailed pterosaurs (Wukongopteridae) from western Liaoning, China
}

\author{
XIAOLIN WANG ${ }^{1}$, ALEXANDER W.A. KELLNER ${ }^{2 *}$, SHUNXING JIANG ${ }^{1,3}$, \\ XIN CHENG ${ }^{1,3}$, XI MENG ${ }^{1}$ and TAISSA RODRIGUES ${ }^{2}$ \\ ${ }^{1}$ Key Laboratory of Evolutionary Systematics of Vertebrates, Institute of Vertebrate Paleontology and Paleoanthropology \\ Chinese Academy of Sciences, PO Box 643, Beijing, 100044, China \\ ${ }^{2}$ Setor de Paleovertebrados, Museu Nacional/UFRJ, Quinta da Boa Vista s/n, São Cristóvão \\ 20940-040 Rio de Janeiro, RJ, Brasil \\ ${ }^{3}$ Graduate University of Chinese Academy of Sciences, Beijing, 100049, China \\ Manuscript received on August 3, 2010; accepted for publication on October 21, 2010
}

\begin{abstract}
Two almost complete long-tailed pterosaurs from the Linglongta, Jianchang County, western Liaoning, China, are described and represent new taxa referred to the non-pterodactyloid clade Wukongopteridae. Kunpengopterus sinensis gen. et sp. nov. differs from other members of this clade mainly by the rounded posterior region of the skull, thick lacrimal process of the jugal and lack of a bony premaxillary crest. This species further shows a soft tissue crest above the frontal, a comparatively larger wing finger, and the proximal segment of the second pedal phalanx of the fifth toe shorter than in other wukongopterids. The second new species is referred to the genus Darwinopterus, D. linglongtaensis sp. nov. based on the posterior region of the skull. It further differs from other wukongopterid pterosaurs by the thin lacrimal process of the jugal, foramen on nasal process rounded, and by having the second pedal phalanx of the fifth toe less curved $\left(115^{\circ}\right)$. Several differences among the Wukongopteridae can be found in the dentition and the feet, suggesting that they might have occupied slightly different ecological niches. The long-tailed Changchengopterus pani is tentatively referred to this clade and new diagnosis for the wukongopterids Wukongopterus lii and Darwinopterus modularis is provided.
\end{abstract}

Key words: Pterosauria, Wukongopteridae, Kunpengopterus, Darwinopterus, Liaoning, China.

\section{INTRODUCTION}

Although the majority of pterosaur specimens consists of incomplete material (e.g., Costa and Kellner 2009, Ibrahim et al. 2010) that in several cases lack detailed stratigraphic data (e.g., Kellner and Campos 1999), there are some areas where complete material of these volant archosaurs have been found in surprisingly large numbers. The main country that has furnished more pterosaur specimens than any other in the last decades is China. This is due to several discoveries from the so called Jehol Biota (e.g., Chang et al. 2003). Pterosaur

Correspondence to: Xiaolin Wang

E-mail: wangxiaolin@ivpp.ac.cn

*Fellow CNPq and FAPERJ specimens were collected mainly in the Early Cretaceous Yixian and Jiufotang Formations (e.g., He et al. 2004), where 13 and 16 species were recognized, respectively (e.g., Wang et al. 2005, 2008, Lü et al. 2008, Andres and Ji 2008, Lü 2010), some of which have spurred controversy (e.g., Ji et al. 1999, Unwin et al. 2000, Wang and Zhou 2006, Lü et al. 2006).

More recently a number of pterosaurs were also recovered from older deposits that crop out particularly in the Linglongta region of the Jianchang County, western Liaoning. The stratigraphy of these deposits is disputed, with some regarding them as part of the Daohugou Formation (e.g., Wang et al. 2009), whereas others refer them to the Tiaojishan Formation (e.g., Lü et 
al. 2010). There are also questions about the age of these deposits, ranging from Middle to Late Jurassic (Zhang 2002, Zhang et al. 2008, Lü et al. 2010) up to the Early Cretaceous (e.g., Wang, Zhou et al. 2005, He et al. 2004).

So far, two pterosaur taxa have been recognized from Linglongta: Wukongopterus lii Wang et al. 2009 and Darwinopterus modularis Lü et al. 2010. Another species, Changchengopterus pani Lü 2009, recovered from a different locality (Mutoudeng Town, Qinglong County), apparently also comes from the same stratigraphic unit (Lü 2009, Wang et al. 2009, Lü et al. 2010).

Here we report two specimens from Linglongta that are also referable to the Wukongopteridae and represent new taxa: Kunpengopterus sinensis gen. et sp. nov. and Darwinopterus linglongtaensis sp. nov. We also discuss the inclusion of previously described taxa to this unusual non-pterodactyloid clade, providing new diagnoses for them.

Anatomical Abbreviations: car - carpus, cdv - caudal vertebra, cor - coracoid, cs - cristospine, $\mathrm{cv}$ - cervical vertebra, d-dentary, dca - distal carpal series, dlca - distal lateral carpal, dpc - deltopectoral crest, dv - dorsal vertebra, f - frontal, fe - femur, fish - fish scales and other elements, fona - foramen nasale, fopn - foramen pneumaticum, gas - gastralia, hu - humerus, hy hyoid bone, il - ilium, is - ischium, j - jugal, 1 - left, la - lacrimal, ltf - lower temporal fenestra, $m$ - maxilla, mcI - metacarpal I, mcII - metacarpal II, mcIII metacarpal III, mcIV - metacarpal IV, n - nasal, naof - nasoantorbital fenestra, obfo - obturator foramen, or - orbit, $\mathrm{p}$ - parietal, pel - pelvis, ph1d4 - first phalanx of manual digit IV, ph2d4 - second phalanx of manual digit IV, ph3d4 - third phalanx of manual digit IV, ph4d4 - fourth phalanx of manual digit IV, pl - palatine, pm - premaxilla, pmcr - premaxillary crest, po postorbital, pph2d5 - second phalanx of pedal digit $\mathrm{V}$, ppu - prepubis, pr - process, prca - proximal carpal, prf - prefrontal, prn - processus nasalis, ptd - pteroid, $\mathrm{pu}$ - pubis, $\mathrm{q}$ - quadrate, $\mathrm{r}$ - right, ra - radius, rapr - retroarticular process, ri - rib, san - surangular, sca - scapula, scl - slerotic ring, ses - sesamoid, sq squamosal, st - sternum, stis - soft tissue, stp - sternal plate, $\mathrm{sv}$ - sacral vertebra, ti - tibia, ul - ulna.

\section{SYSTEMATIC PALEONTOLOGY}

PTEROSAURIA Kaup 1834

WUKONGOPTERIDAE

Wang, Kellner, Jiang and Meng 2009

Type genus: Wukongopterus Wang, Kellner, Jiang and Meng 2009.

Definition: The most recent common ancestor of $\mathrm{Wu}$ kongopterus lii and Kunpengopterus sinensis gen. et sp. nov. and all its descendants.

Included taxa: Wukongopterus lii, Darwinopterus modularis, Darwinopterus linglongtaensis sp. nov., Kunpengopterus sinensis gen. et sp. nov., and Changchengopterus pani.

Synapomorphies: Non-pterodactyloid pterosaurs with confluent naris and antorbital fenestra; maxillary ramus of the jugal long, anteriorly projected and splint-like; free lateral nasal process; quadrate inclined backwards for about $120^{\circ}$; mandibular symphysis short (less than $25 \%$ the length of the lower jaw); cervical vertebrae more elongated than in other non-pterodactyloids; cervical ribs reduced; length of the wing metacarpal about half the length of the first wing finger phalanx; first wing finger phalanx shorter than fourth wing finger phalanx (modified from Wang et al. 2009).

\section{Wukongopterus}

Wang, Kellner, Jiang and Meng 2009

Type species: Wukongopterus lii Wang, Kellner, Jiang and Meng 2009.

Diagnosis: The same as for the species.

\section{Wukongopterus}

Wang, Kellner, Jiang and Meng 2009

Emended diagnosis: Wukongopterid pterosaur with the following combination of characters that distinguishes it from other members of this clade (autapomorphies are marked with an asterisk): first two pairs of premaxillary teeth protruding beyond the dentary almost vertical*; dentition formed by short cone-shaped and very pointed teeth; preacetabular portion of the ilium reduced*; strongly curved second pedal phalanx of the fifth toe with an angle between the proximal and distal segment about $70^{\circ}$; proximal segment of the second 
pedal phalanx of the fifth toe elongated* (modified from Wang et al. 2009).

Darwinopterus Lü, Unwin, Jin, Liu and Ji 2010

Type species: Darwinopterus modularis Lü, Unwin, Jin, Liu and Ji 2010.

Included taxa: Darwinopterus modularis and Darwinopterus linglongtaensis sp. nov.

Emended diagnosis: Wukongopterid pterosaur with the following combination of characters that distinguishes this genus from others of this clade: posterior region of the skull elongated; presence of a bony premaxillary crest that starts about the anterior margin of the nasoantorbital fenestra; dorsal margin of the premaxillary crest serrated; thin nasal process; preacetabular region of the ilium elongated (modified from Lü et al. 2010).

\section{Darwinopterus modularis}

Lü, Unwin, Jin, Liu and Ji 2010

Emended diagnosis: Wukongopterid pterosaur with the following combination of characters that distinguishes it from other members of this clade (autapomorphies are marked with an asterisk): posterior region of the skull more elongated than in Darwinopterus linglongtaensis sp. nov.; dentition formed by well-spaced spikelike teeth* (modified from Lü et al. 2010, here based only on the holotype).

Darwinopterus linglongtaensis sp. nov.

Etymology: From Linglongta, where the holotype of this new species was discovered.

Holotype: Almost complete and well-articulated skeleton housed in the Institute of Vertebrate Paleontology and Paleoanthropology (Chinese Academy of Sciences), Beijing, under the number IVPP V16049 (Figs. 1-5).

Locality and horizon: Linglongta, Jianchang County, western Liaoning, China, Daohugou Bed (Formation) or Tiaojishan Formation.

Diagnosis: Wukongopterid pterosaur with the following combination of characters that distinguishes it from other members of this clade (autapomorphies are marked with an asterisk): posterior region of the skull less elongated han in Darwinopterus modularis; dentition formed by short cone-shaped teeth; lacrimal process of the jugal comparatively thin*; foramen on nasal process rounded*; curved second pedal phalanx of the fifth toe with an angle between the proximal and distal segment about $115^{\circ}$.

Description: The holotype of Darwinopterus linglongtaensis is preserved in a slab formed by light grey shale. The specimen is almost completely articulated except for some portions of the vertebral column that moved from their natural position as the right pelvic elements (ilium, pubis and ischium) (Fig. 1). Some elements are missing, particularly from the neck.

The skull of Darwinopterus linglongtaensis (IVPP V16049) is exposed in right lateral view (Fig. 2). Unfortunately part of the bone surface on the lateral side was broken off leaving only an impression on the matrix. However, it is clear that this taxon had a confluent external naris and antorbital fenestra. The length between the squamosal and the tip of the premaxilla is $119.2 \mathrm{~mm}$ and, therefore, almost $12 \%$ larger than Kunpengopterus sinensis (IVPP V16047). Also as the former, the orbit is large and has the ventral margin wider than in Darwinopterus modularis.

A well-developed premaxillary crest runs above the dorsal margin of the skull reaching about the middle region of the orbit and not extending posteriorly above the occipital region. This crest has a serrated dorsal margin (Fig. 3a), which suggests the existence of a horny covering. The nasal has an elongated nasal process that has a broad dorsal part but gets ventrally thinner (Fig. 3c). A well-developed oval pneumatic foramen pierces this bone.

The dorsal part of the posterior region of the skull is not very well preserved, which impedes the establishment of the limits of most bones. The postorbital, a triradiated bone, is displaced backwards from its natural position. The posterior region of the skull, formed by the parietal, is slightly extended backwards, although not to the same degree as observed in Darwinopterus modularis. The jugal has a thin, slightly anteriorly directed lacrimal process (Fig. 3b). The maxillary process is elongated and thin, as observed in other wukongopterids (e.g., Wukongopterus, Darwinopterus). The 


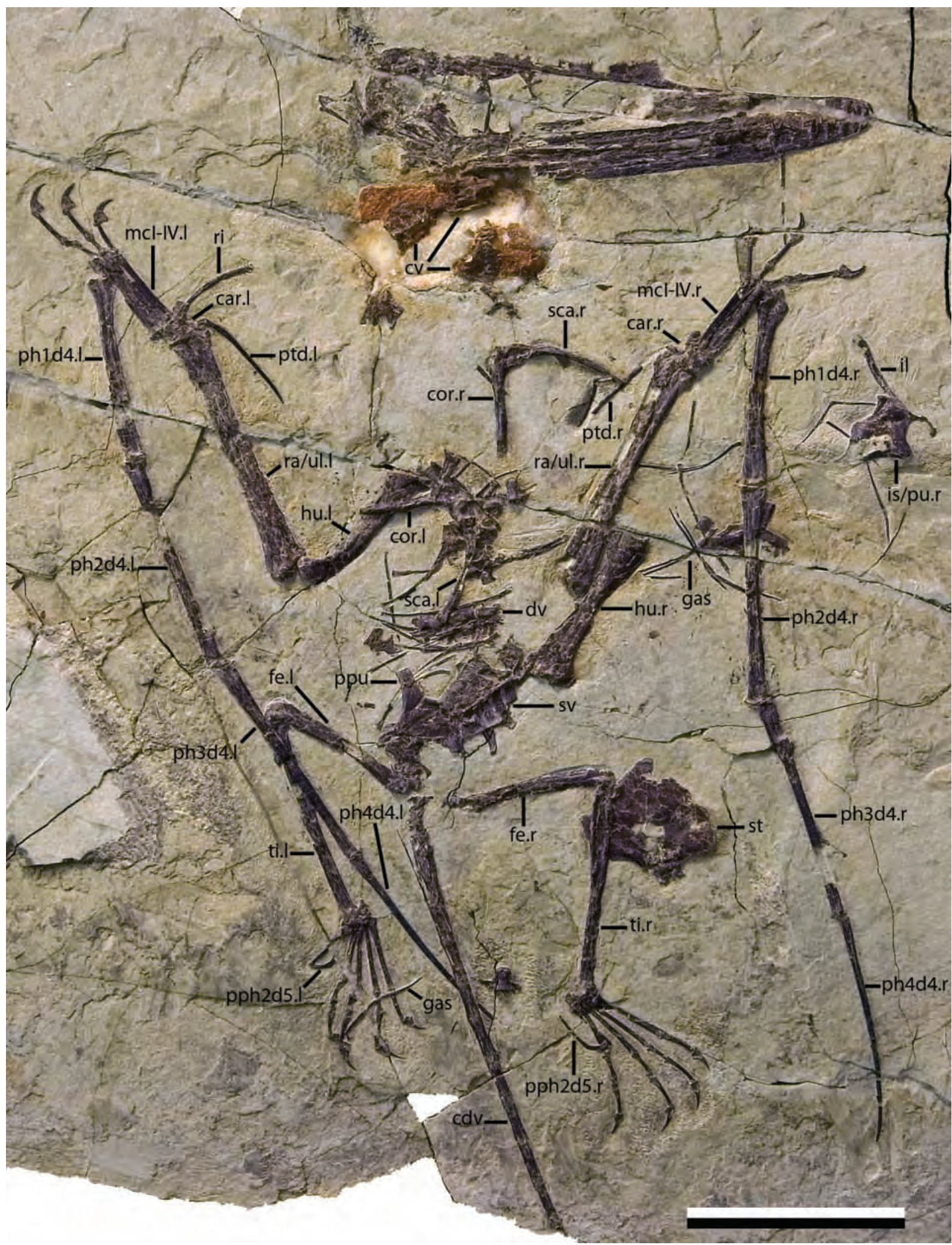

Fig. 1 - Darwinopterus linglongtaensis sp. nov., holotype (IVPP V16049). Scale bar: 50 mm. 

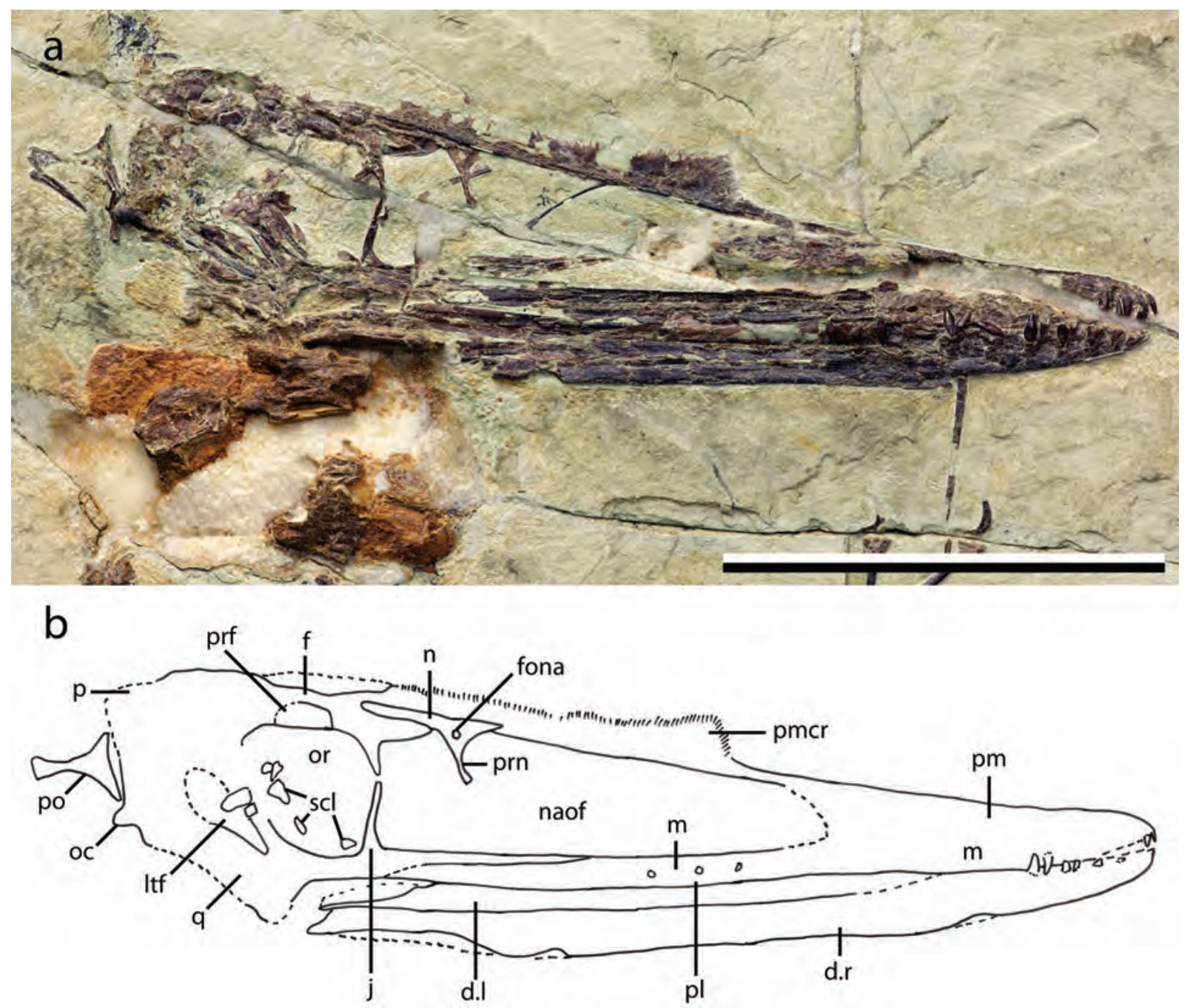

Fig. 2 - Darwinopterus linglongtaensis sp. nov. (IVPP V16049). a, skull and b, drawing. Scale bar: 50 mm.

quadrate, also not well preserved, is inclined posteriorly, differing from most other non-pterodactyloid pterosaurs (except for other wukongopterids). A rounded occipital condyle can be observed, directed posteroventrally.

Overall the shape of the skull in Darwinopterus linglongtaensis suggests a high skull, particularly at the posterior portion, higher than both Kunpengopterus sinensis and Darwinopterus modularis. It shares with the latter a bony premaxillary crest and the posterior extension of the skull, albeit less developed. Darwinopterus linglongtaensis also has a thinner lacrimal process than Kunpengopterus, and shows a rounded pneumatic foramen piercing the nasal process that, if present in Darwinopterus modularis, was not reported (Lü et al. 2010).

The postcranial elements of the holotype of Darwinopterus linglongtaensis (IVPP V16049) show a distinct degree of fusion. Among them, the extensor tendon process of the first wing finger phalanges and some elements of the proximal and distal carpal series are unfused (Fig. 4c), whereas the sacral vertebrae are fused (Fig. 5a). In some cases, bones are firmly connected, but show a distinct suture line indicating that they are not co-ossified like the scapula with the coracoid (Fig. 3e) and the proximal tarsals with the tibia (Fig. 5d, e). Based on the ontogenetic information known for more derived pterosaurs (e.g., Bennett 1993), this specimen does not 


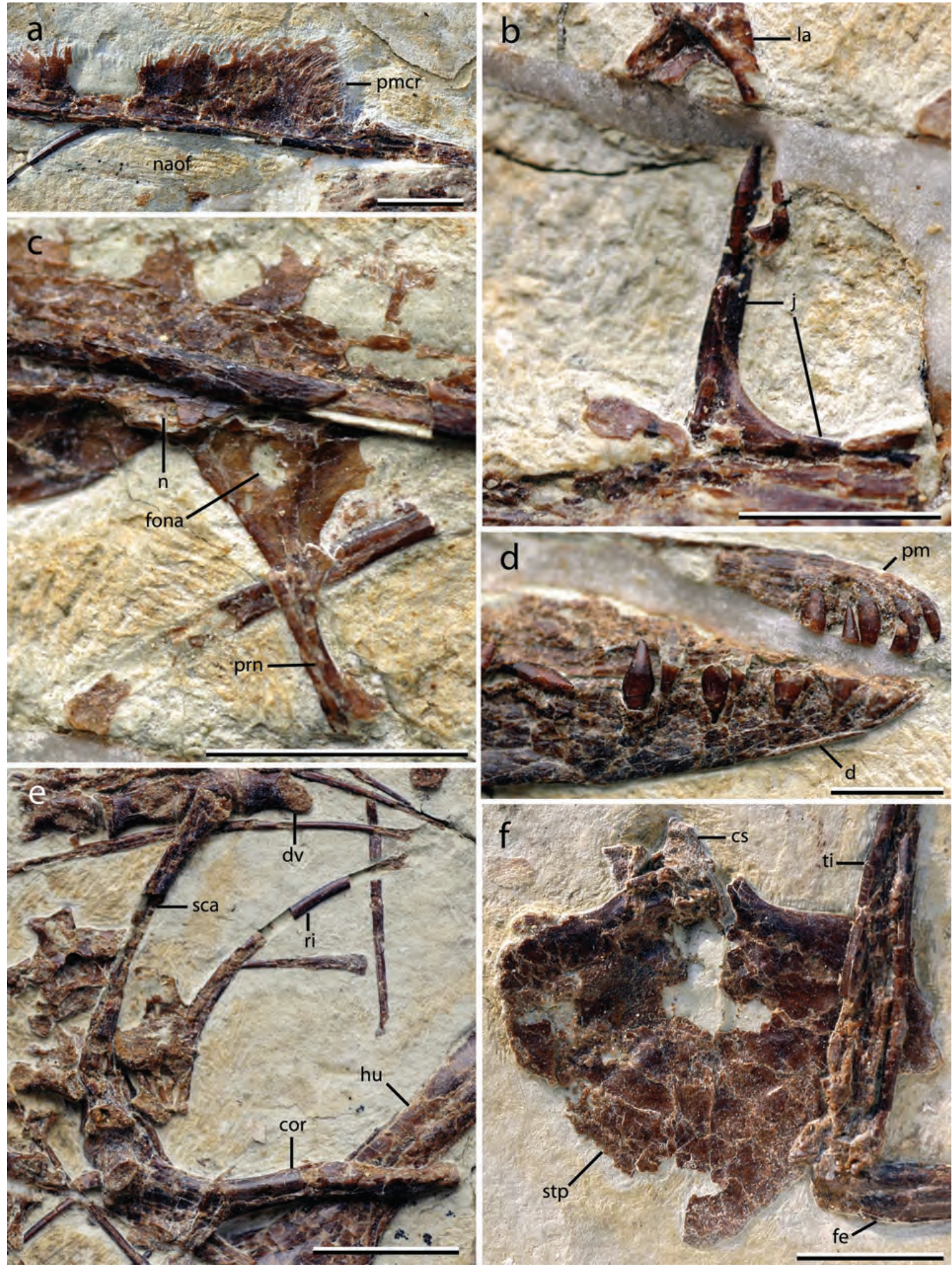

Fig. 3 - Darwinopterus linglongtaensis sp. nov. (IVPP V16049). a, detail of premaxillary crest; b, detail of the jugal; c, detail of the nasal; d, distal part of the jaws; e, left scapulocoracoid; f, sternum. Scale bars: a, b, c: $5 \mathrm{~mm}$; d, e, f: $10 \mathrm{~mm}$. 



Fig. 4 - Darwinopterus linglongtaensis sp. nov. (IVPP V16049). a, part of the left wing; b, right humerus; c, detail of the left carpal region; d, manual unguals; e, pedal unguals. Scale bars: a: $40 \mathrm{~mm}$; b, c: $10 \mathrm{~mm}$; d, e: $5 \mathrm{~mm}$.

represent a juvenile or a very young animal, but rather a sub-adult at the time of death.

The remains of three cervical vertebrae are preserved. The most complete one is observed from ventral view and is strongly procoelic, lacking postexapophyses. They are moderately elongated, which is a wukongopterid feature. The dorsal vertebrae are rather scattered in the matrix. The sacral vertebrae are well preserved and formed by five elements, four of which are fused with each other by the distal ends of the transverse processes and the neural spines (Fig. 5a). The most anterior sacral is clearly in the process of fusing with the remaining ones. Since the posterior end of the last sacral is covered by pelvic bones, it is not 

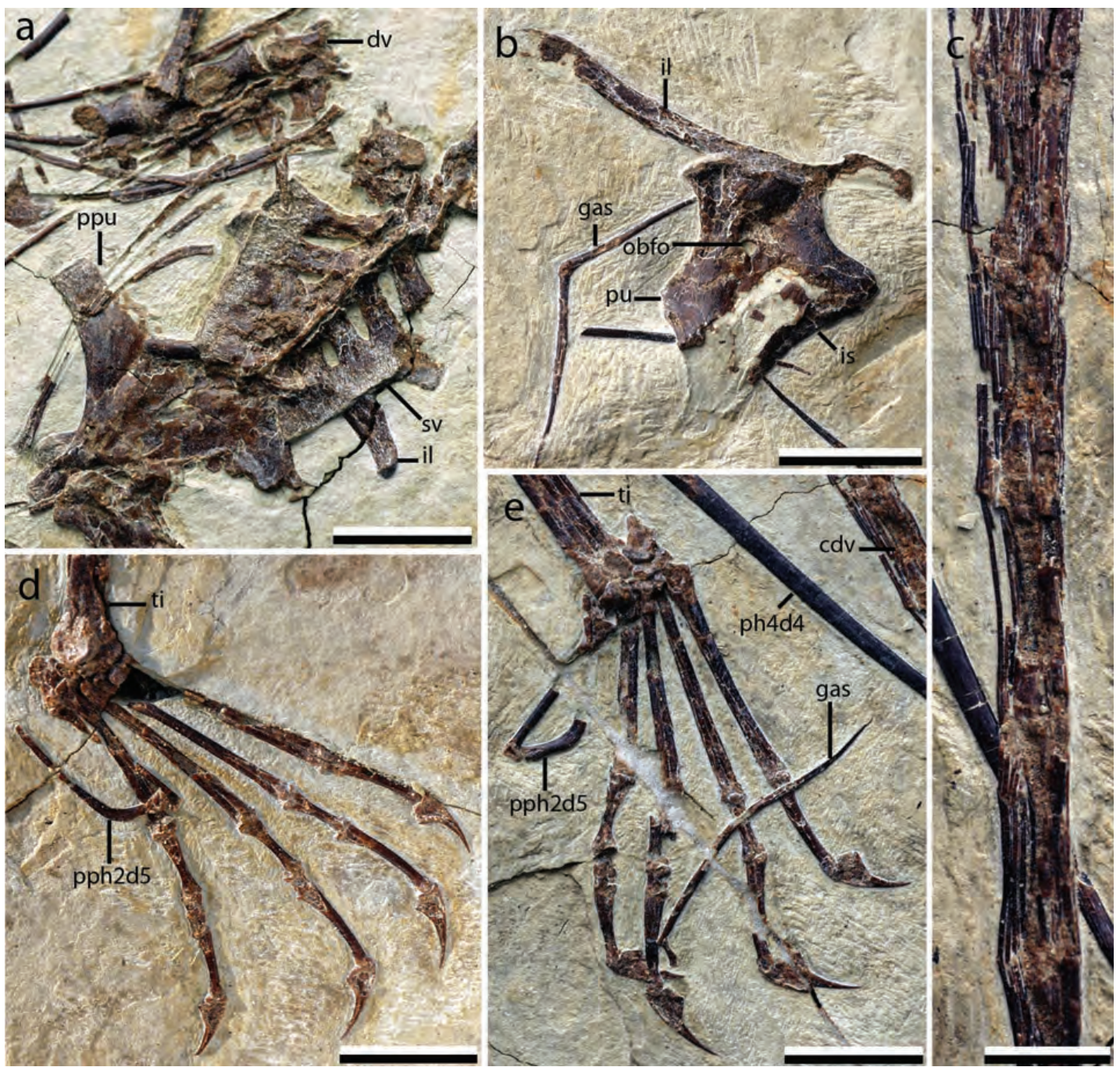

Fig. 5 -Darwinopterus linglongtaensis sp. nov. (IVPP V16049). a, detail of sacral vertebrae and prepubis; b, pelvis; c, part of the tail; d, right foot; e, left foot. Scale bars: a, b, d, e: $10 \mathrm{~mm}$;, $5 \mathrm{~mm}$.

clear whether a caudal vertebra was incorporated to the sacrum. The tail has the first proximal caudal vertebrae short, but the remaining ones are quite elongated and enclosed by rod-like bony structures formed by extensions of the zygapophyses (Fig. $5 \mathrm{c}$ ). The sternum is almost complete, lacking the cristospine (Fig. 3f). This heart-shaped bone is exposed in dorsal view and has the anterior margin slightly more concave compared to Kunpengopterus sinensis. Several elements of the gastralia are found scattered around. They are very thin and curved.

The scapula is considerably longer than the coracoid (Fig. 3e; see Table). The left humerus is exposed laterally and an imprint in the matrix indicates that the deltopectoral crest was developed (Fig. 4a), but more confined to the proximal portion of the humerus, which is regarded as a plesiomorphic trait within pterosaurs (e.g., Wang et al. 2009). The right humerus is exposed in dorsal view and shows a tiny foramen in the proximal half (Fig. 4b) that might also be a diagnostic feature of this taxon. Such a foramen, which could be either pneumatic or nutrient, has never been reported in a non-pterodactyloid pterosaur before, together with a developed process on the anterior surface of the distal articulation of the humerus. This process, however, is not evident on the right humerus. Radius and ulna are well preserved, with the diameter of the former smaller but larger than half that of the ulna. 
TABLE I

Measurements of some species of the Wukongopteridae (in mm).

\begin{tabular}{|c|c|c|c|}
\hline $\begin{array}{c}\text { Bones/ } \\
\text { taxa }\end{array}$ & $\begin{array}{c}\text { Wukongopterus } \\
\text { lii }\end{array}$ & $\begin{array}{l}\text { Darwinopterus } \\
\text { linglongtaensis }\end{array}$ & $\begin{array}{c}\text { Kunpengopterus } \\
\text { sinensis }\end{array}$ \\
\hline sca & $\begin{array}{l}34.1(r) \\
32.9(1)\end{array}$ & $31.1(\mathrm{r})$ & $\sim 28.8(\mathrm{r})$ \\
\hline cor & $\sim 25.3(\mathrm{r})$ & $\begin{array}{l}24.9(\mathrm{r}) \\
26.3(1)\end{array}$ & $\sim 23.8(\mathrm{r})$ \\
\hline hu & $\sim 38.7(\mathrm{r})$ & $\begin{array}{l}40.4(r) \\
39.9(1)\end{array}$ & $\sim 36.2(\mathrm{r})$ \\
\hline ul & $\sim 62.1(\mathrm{r})$ & $\begin{array}{l}58.0(\mathrm{r}) \\
61.2(1)\end{array}$ & $\sim 59.2$ (1) \\
\hline mcIV & 22.9 (1) & $\begin{array}{l}22.5(r) \\
23.6(1)\end{array}$ & $\sim 23(1)$ \\
\hline ph1d4 & $\sim 45.7(\mathrm{r})$ & $\begin{array}{l}46.2(r) \\
44.4(1)\end{array}$ & $54.2(\mathrm{r})$ \\
\hline $\mathrm{ph} 2 \mathrm{~d} 4$ & $56.8(\mathrm{r})$ & $\begin{array}{l}50.7(\mathrm{r}) \\
52.1(1)\end{array}$ & $58.0(\mathrm{r})$ \\
\hline $\mathrm{ph} 3 \mathrm{~d} 4$ & $\begin{array}{l}58.3(\mathrm{r}) \\
59.3(1)\end{array}$ & $\begin{array}{l}53.2(\mathrm{r}) \\
53.7(1)\end{array}$ & $59.2(\mathrm{r})$ \\
\hline ph4d4 & $51.5(1)$ & $\begin{array}{l}53.6(\mathrm{r}) \\
53.7(1)\end{array}$ & $\sim 48.8$ (l) \\
\hline fe & $\begin{array}{l}33.3(\mathrm{r}) \\
35.6(1)\end{array}$ & $\begin{array}{l}39.4(\mathrm{r}) \\
40.1(1)\end{array}$ & $\begin{array}{l}\sim 39.3(\mathrm{r}) \\
\sim 41.1(\mathrm{l})\end{array}$ \\
\hline $\mathrm{ti}$ & $52.8(\mathrm{r})$ & $\begin{array}{l}49.8(r) \\
49.6(1)\end{array}$ & 54.5 (1) \\
\hline $\mathrm{mt} 3$ & $\begin{array}{c}\sim 17.2(\mathrm{r}) \\
16.8(\mathrm{l})\end{array}$ & $17.0(\mathrm{r})$ & $\begin{array}{l}21.8(\mathrm{r}) \\
20.7(\mathrm{l})\end{array}$ \\
\hline $\mathrm{mt} 4$ & $\begin{array}{c}\sim 14.5(\mathrm{r}) \\
15.0(\mathrm{l})\end{array}$ & $\begin{array}{l}14.2(\mathrm{r}) \\
14.2(1)\end{array}$ & 17.9 (r) \\
\hline $\mathrm{pt}$ & $+7.3(\mathrm{r})$ & 28.9 (1) & $\sim 25.8(1)$ \\
\hline
\end{tabular}

The carpal region of both sides is well preserved. Some elements of the proximal and distal carpal series are unfused (Fig. 4c). In both sides, the distal lateral carpal shows a well-developed sesamoid in the fovea carpalis, and the elongated, slightly curved pteroid is clearly articulated with the proximal carpal series. A sesamoid is present between the proximal portion of the pteroid shaft and the proximal carpal series.

As observed in Kunpengopterus, the wing metacarpal (metacarpal IV) is more elongated relative to the first wing finger phalanx (ph1d4/mcIV: left side 1.88, right side 2.05) and humerus (hu/mcIV: left side
1.69 , right side 1.80) than in other non-pterodactyloids, but shorter compared to pterodactyloids (e.g., Kellner 2003). Metacarpals I-III are thin, subequal in length and articulate with the distal carpal series. As in other wukongopterids, the first phalanx of the wing finger has concave anterior and convex posterior margins, respectively. The wing finger phalanges are very well preserved and clearly show that the first wing phalanx is the smallest of all. Compared to Kunpengopterus sinensis, the present taxon has a shorter wing finger, despite having a larger humerus (and skull).

Regarding the pelvic girdle, the right ilium fused 
with the pubis and ischium can be observed in medial view (Fig. 5b), whereas the correspondent bones from the left side are partially covered by the sacral vertebrae. The preacetabular portion of the ilium is rather long, more developed than in Wukongopterus and other non-pterodactyloid pterosaurs such as Dimorphodon and Campylognathoides (see Wellnhofer 1978, Padian 2008b).

The femur is only slightly curved and the femur head (of left side) lies at an angle close to $150^{\circ}$ with the shaft. On the left and right sides a thin splint-like fibula that apparently does not reach the tarsus can be observed. The feet (Fig. 5d, e) are well preserved, showing a phalangeal formula of 2:3:4:5:2. Metarsals I and II are the largest, being subequal in size. Metatarsal V is short and has a broad proximal portion, being less elongated compared with Kunpengopterus and Wukongopterus. It bears two pedal phalanges (a plesiomorphic trait), with the second being boomerang-shaped. The angle between the proximal and distal portions of the latter is about $115^{\circ}$, which is larger than in Wukongopterus (Wang et al. 2009) but smaller than in Kunpengopterus. Pedal unguals (Fig. 4e) are more elongated, thinner and comparatively smaller than manual unguals (Fig. 4d), a generally common trait within pterosaurs. The curvature of the pre-ungual phalanx of the first and second digits is less pronounced than in Kunpengopterus.

\section{Kunpengopterus gen. nov.}

Etymology: Kunpengopterus, from Kun Peng, an ancient mythological figure from China regarded as being a very strange flying animal, and pterus, from the Greek language meaning wing.

Type species: Kunpengopterus sinensis sp. nov., type by monotypy.

Diagnosis: The same as for the species.

\section{Kunpengopterus sinensis sp. nov.}

Etymology: From the Greek term sino meaning pertaining to China, where this new species was discovered.

Holotype: Almost complete skeleton with complete skull and lower jaw housed in the Institute of Vertebrate Paleontology and Paleoanthropology (Chinese
Academy of Sciences), Beijing, under the number IVPP V16047 (Figs. 6-8).

Locality and horizon: Linglongta, Jianchang County, western Liaoning, China. Daohugou Bed (Formation) or Tiaojishan Formation.

Diagnosis: Wukongopterid pterosaur with the following combination of characters that distinguishes it from other members of this clade (autapomorphies are marked with an asterisk): posterior region of the skull rounded*; dentition composed of short cone-shaped teeth; lacrimal process of the jugal thick; absence of a bony premaxillary crest; presence of a soft tissue crest above the frontal*; broad nasal process*; foramen on nasal process elliptical with main axis subvertical*; curved second pedal phalanx of the fifth toe with an angle between the proximal and distal segments about $137^{\circ}$; ; proximal segment of the second pedal phalanx of the fifth toe shorter than in other wukongopterids*.

Description: Kunpengopterus sinensis (IVPP V16047) is preserved in a grey shale slab with several bones of the skeleton associated but not articulated (Fig. 6). When collected, the specimen was broken in a few parts and later put together. One mass of dark matter is observed close to the skull. It is not part of the pterosaur, but scales and other fish elements (Fig. 6). Soft tissue formed by elongated dark unbranched fibers similar to the pycnofibers reported in other pterosaurs (Wang et al. 2002, Kellner et al. 2010) is observed above the frontal (Fig. 8a). Although not as well preserved as reported from some other deposits (e.g., Kellner 1996) and differing from the typical structures found in fossilized feathers (e.g., Kellner et al. 1994), this soft tissue is here interpreted as the remains of a soft cranial crest. Such a structure was previously observed in a similar position in the archaeopterodactyloid Gegepterus from the Yixian Formation (Wang et al. 2007). Dorsal and anteriorly to this dark mineralized substance (which is possible organic in nature), there are some yellow stains in the matrix. Although no UV photography was taken on this specimen, it would possibly reveal an extensive dorsal projection of the soft portion of the cranial crest, as reported in other pterosaur specimens (e.g., Frey and Tischlinger 2000). No other region with soft tissue preservation could be detected in this specimen. 


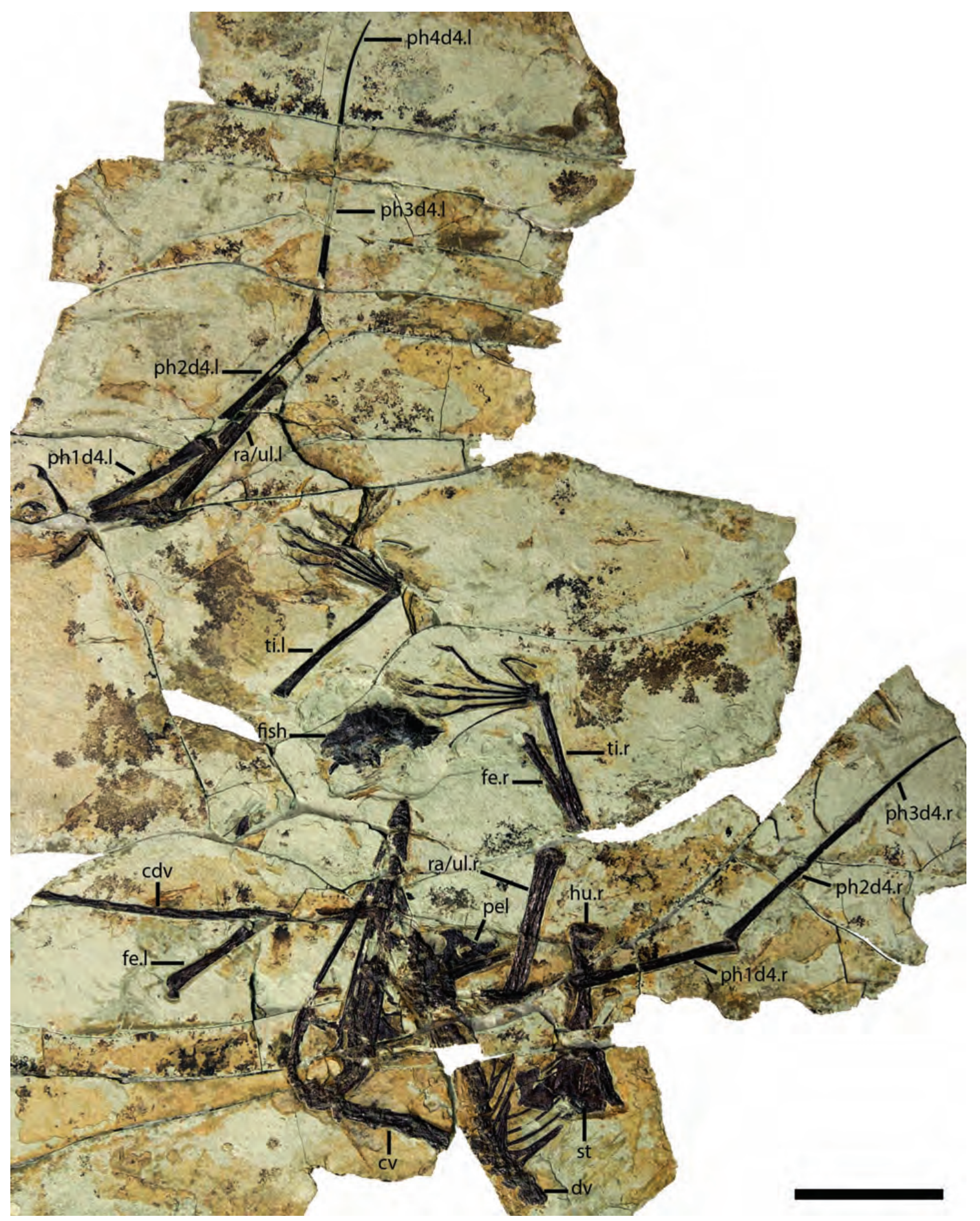

Fig. 6 - Kunpengopterus sinensis gen. et sp. nov., holotype (IVPP V16047). Scale bar: $50 \mathrm{~mm}$.

The skull of Kunpengopterus sinensis is complete and exposed in right lateral view (Fig. 7). It is elongated (length squamosal - tip of premaxillae: $106.9 \mathrm{~mm}$ ). As observed in Wukongopterus and Darwinopterus, the ros- tral portion (anterior to the external naris: $\sim 40.5 \mathrm{~mm}$ ) is comparatively shorter than in other non-pterodactyloid pterosaurs such as Rhamphorhynchus (e.g., Wellnhofer 1975, Wang et al. 2009, Lü et al. 2010). The orbit is 


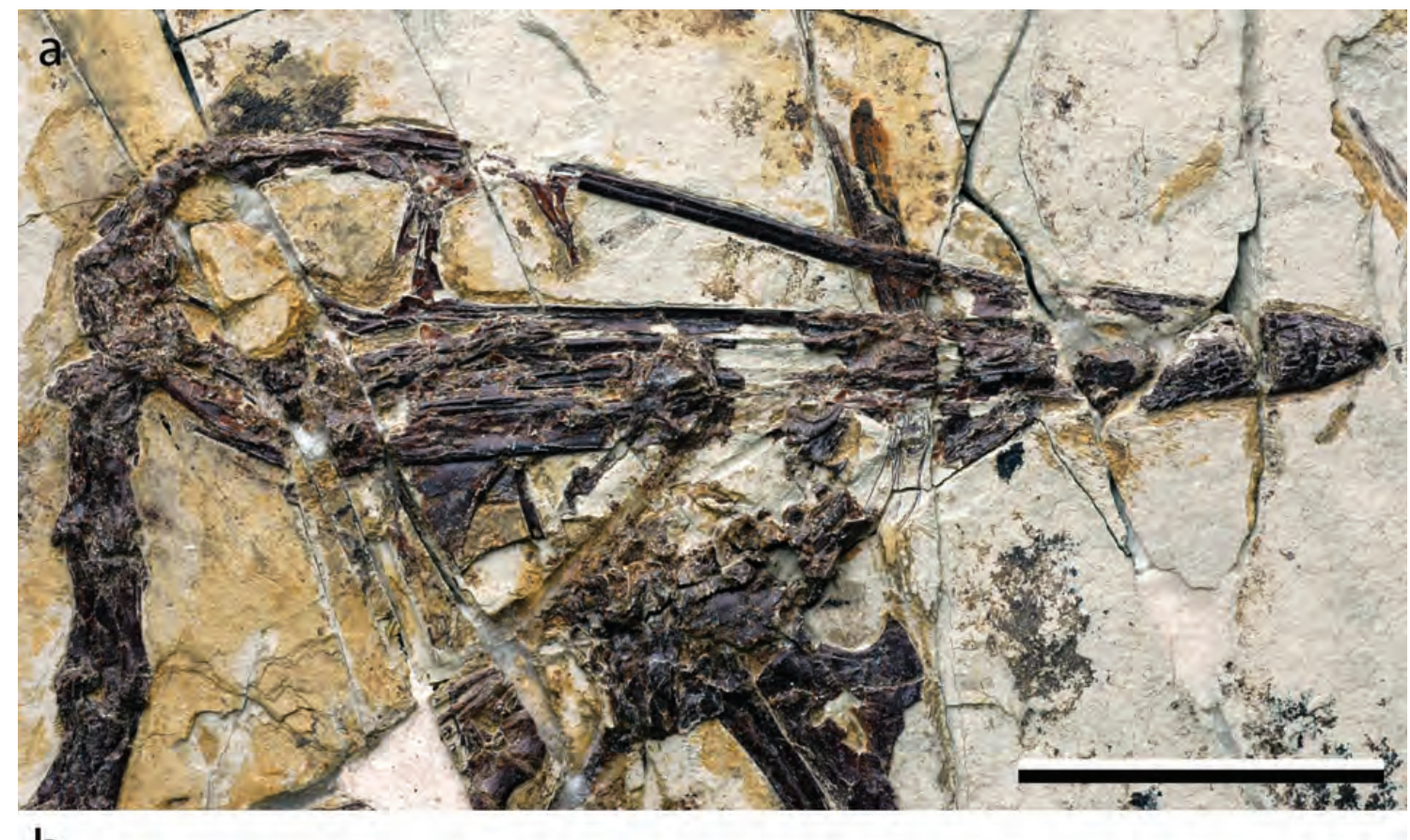

b

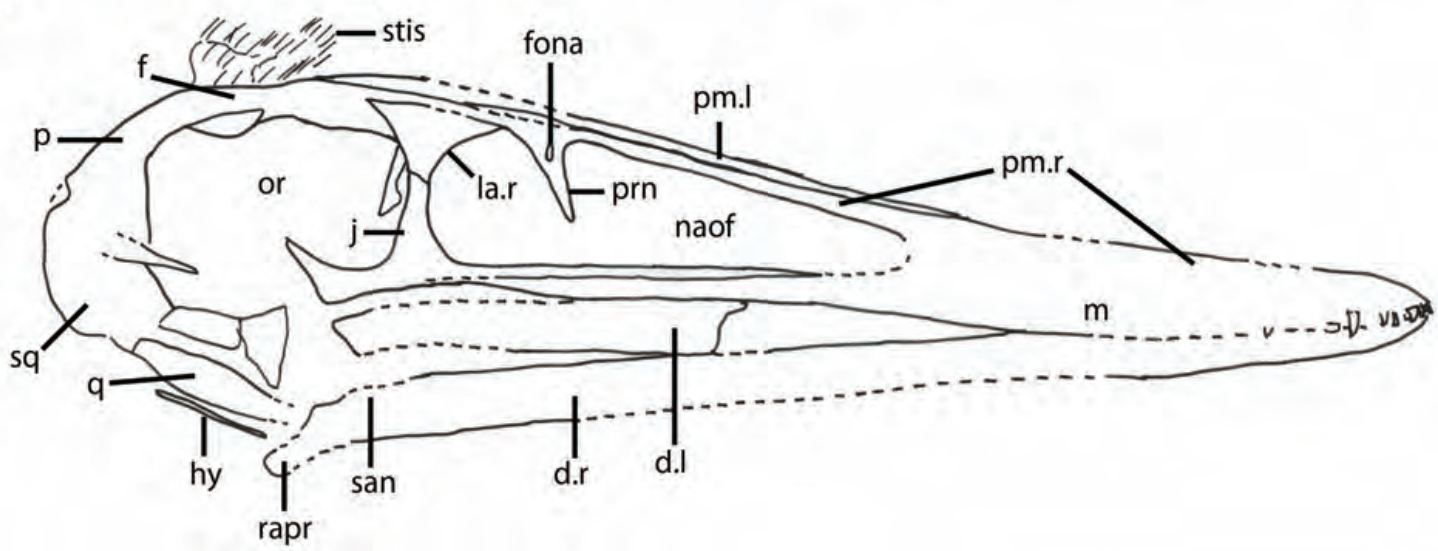

Fig. 7 - Kunpengopterus sinensis gen. et sp. nov. (IVPP V16047). a, skull and b, drawing. Scale bar: $50 \mathrm{~mm}$.

large and has the lower margin more rounded compared with Darwinopterus modularis. The naris and antorbital fenestra are confluent and form a nasoantorbital fenestra, a rather derived trait within pterosaurs (e.g., Kellner 2003, Unwin 2003). No information about the temporal openings can be retrieved from this specimen.

A low ridge runs over part of the cranial dorsal margin, but does not form a bony premaxillary crest. Nonetheless, as pointed out before, soft tissue is present above the frontal showing that this species bears a soft tissue cranial crest whose dorsal and anterior extensions are presently unknown. Posteriorly, the premaxilla con- tacts the frontal and also does not form a posterior premaxillary bony crest that has been observed in several pterosaurs, particularly in the Pterodactyloidea (e.g., Wellnhofer 1991, Kellner 2003, Unwin 2003), but also in some more primitive non-pterodactyloids (e.g., Dalla Vecchia et al. 2002, Dalla Vecchia 2009).

The nasal has an elongated, broad nasal process (Fig. 8c) that occupies a lateral position and is directed anteroventrally. This process bears an elliptical foramen whose main axis is subvertical. The bones of the skull roof were laterally compressed and their limits are hard to distinguish. The prefrontal is elongated and 

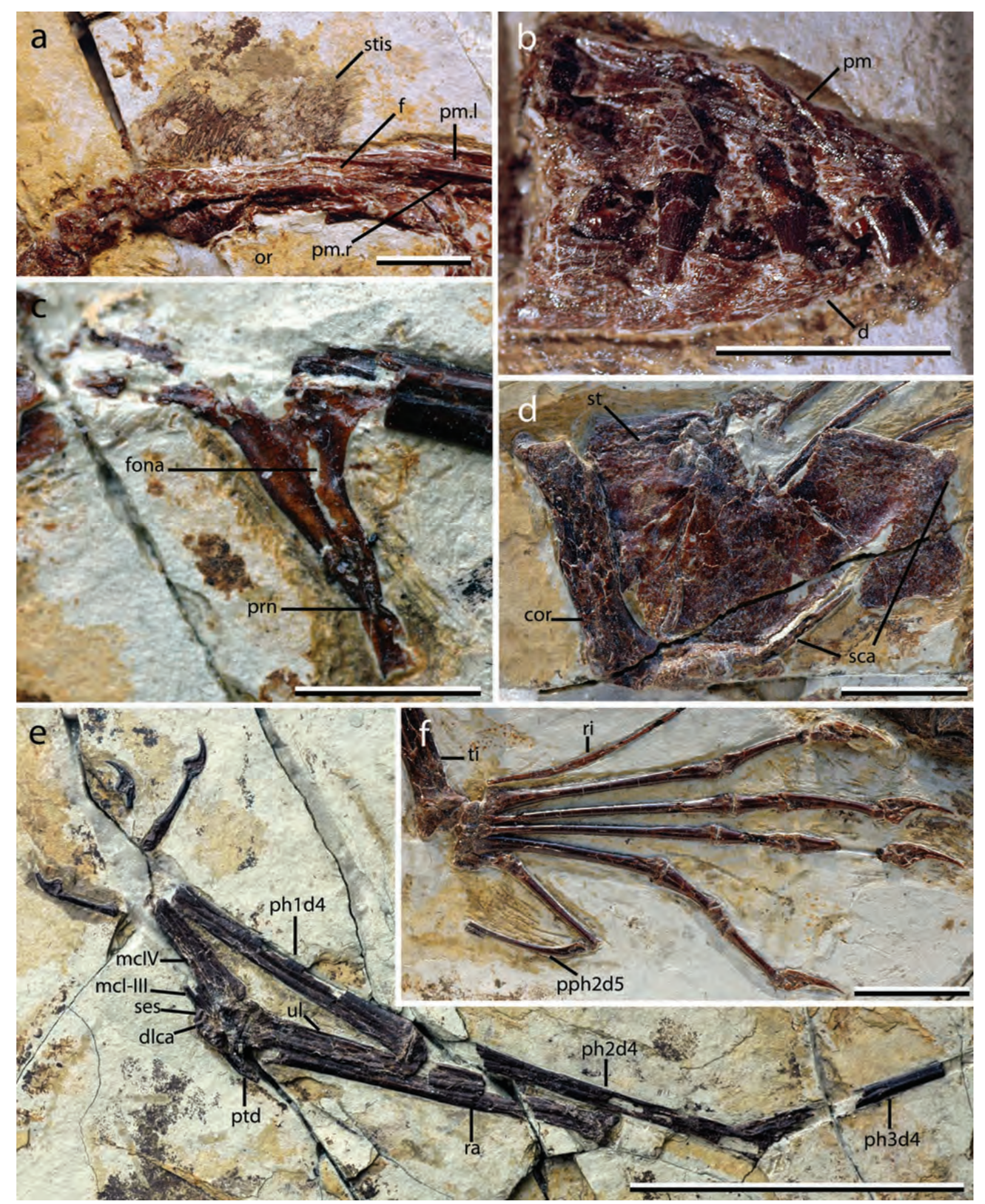

Fig. 8 - Kunpengopterus sinensis gen. et sp. nov. (IVPP V16047). a, detail of the soft tissue; b, distal part of the jaws; $c$, detail of the nasal; d, sternum; e, part of the left wing; f, right foot. Scale bars: a, b, c: $5 \mathrm{~mm}$; d, f: $10 \mathrm{~mm}$; e: $50 \mathrm{~mm}$. 
forms the dorsoanterior margin of the orbit. The posterior portion of the skull, which is formed by the parietal (Fig. 7), is rounded and does not extend posteriorly. The jugal has a broad, almost perpendicular lacrimal process and an elongated, anteriorly directed thin (splint-like) maxillary process that forms part of the lower margin of the nasoantorbital fenestra. No information from the palatal and occipital region is available on this specimen.

The lower jaw (length: $90.0 \mathrm{~mm}$ ) of Kunpengopterus sinensis is tightly connected with the skull. The symphysis in this taxon is short, having a maximum estimated length of $22 \mathrm{~mm}$ and being, therefore, less than $25 \%$ the length of the lower jaw. No evidence of a dentary sagittal crest (made of bone or soft tissue) was observed.

The dentition of Kunpengopterus sinensis is composed of cone-shaped, peg-like teeth (Fig. 8b). The exact number of teeth cannot be determined in none of the jaws but, based on the preserved portion, the last tooth was apparently placed anterior to the anterior margin of the nasoantorbital fenestra. If correct, this can be considered another diagnostic feature that further distinguishes this taxon from other wukongopterids.

Compared to other non-pterodactyloid pterosaurs, the skull of Kunpengopterus sinensis has a rounded posterior outline, similar to the condition observed in Rhamphorhynchus and Sordes but differing from Darwinopterus (Wellnhofer 1975, 1991, Lü et al. 2010). The thick lacrimal process is also observed in Darwinopterus modularis, but absent in Darwinopterus linglongtaensis (see below). The nasal process, a feature typical of derived pterosaurs but absent in non-pterodactyloids (e.g., Kellner 2003, Wang et al. 2008), is rather broad, differing from the thinner condition observed in Darwinopterus. The symphysis of Kunpengopterus displays the primitive condition by being reduced as observed in Darwinopterus and Wukongopterus, and being less developed than in Rhamphorhynchus and Dorygnathus (Kellner 2003). The dentition is similar to the one observed in Wukongopterus lii, differing only in being less pointed than in the latter. Furthermore, the two anteriormost upper teeth are almost vertical in Wukongopterus, whereas being slightly inclined anteriorly in Kunpengopterus.

The postcranial skeleton of the sole specimen known from Kunpengopterus sinensis (IVPP V16047) shows signs of a fully ontogenetically mature individual, having several elements fused such as the scapulocoracoid and the proximal and distal carpal series (Fig. 8e), which at least in derived pterosaurs are normally unfused in subadult or juvenile specimens (e.g., Bennett 1993). Even the proximal tarsal elements (Fig. 8f), also unfused in young derived flying reptiles (Kellner 2004), are strongly connected with the tibia without showing the suture line.

The cervical series is almost complete, consisting of the first five (including the axis and presumably also the atlas, not visible) and the last two cervical vertebrae. Except for the axis and the last cervical element, the others have an elongated centrum, with cervical vertebrae 3 to 5 being the longest (Fig. 7). In some of them a small cervical rib is noted. No pneumatic foramen piercing the lateral surface of the centrum or the neural arch could be observed. The neural spine is blade-like and comparatively low, getting higher in the posterior elements. The dorsal vertebral series is partially preserved and no elements were fused into a notarium. The tail is long, formed by several caudal vertebrae that are elongated and enclosed by long bony rod-like structures formed by the extensions of the zygapophyses, a primitive feature within Pterosauria. The sternum (Fig. 8d) is not well preserved in this specimen. However, it forms a large bony plate with the anterior margin straight and slightly inclined posteriorly.

As pointed out before, the scapula and coracoid are fused. Although not well preserved, it is clear that the scapula is the longer element. The humerus lacks any pneumatic foramen and the deltopectoral crest is not preserved. The diameter of the radius is smaller, but not half of the diameter of the ulna.

Only the carpal region of the left side is preserved (Fig. 8e). All elements of the proximal and distal series are fused. The distal lateral carpal shows a welldeveloped sesamoid in the fovea carpalis. The pteroid is elongated, slightly curved and clearly articulated with the proximal carpals series. The wing metacarpal (metacarpal IV) is more elongated relative to the first wing finger phalanx (ph1d4/mcIV: 2.36) and humerus $(\mathrm{hu} /$ mcIV: 1.57) than in other non-pterodactyloid pterosaurs, but shorter compared to pterodactyloids (e.g., 
Kellner 2003). Metacarpals I-III articulate with the distal carpal series. The anterior margin of the first phalanx of the wing finger is concave and the posterior convex, as observed in the Dsungaripteridae (Wellnhofer 1978, Unwin 2003). This bone is also the smallest relative to the other wing finger phalanx, here regarded as a synapomorphy of the Wukongopteridae.

The femur is rather straight, with the femur head forming an angle between $125^{\circ}$ and $130^{\circ}$ with the shaft. Tibia is elongated, almost $40 \%$ longer than the femur. The feet are well preserved (Fig. 8f), with the metatarsal II being the largest and metatarsals I and III subequal in size, followed by metatarsal IV. Metatarsal V is small and bears two phalanges, with the second one having the proximal portion comparatively short. The angle between the proximal and distal segments is about $137^{\circ}$. Pedal unguals are more elongated, thinner and comparatively smaller than manual unguals. It is interesting to note that the pre-ungual phalanx of the first and second digits is curved. The pedal phalangeal formula is $2: 3: 4: 5: 2$.

\section{DISCUSSION}

As Wang et al. (2009) pointed out, the basic anatomy of Wukongopterus lii is quite different from any other pterosaurs' anatomy by uniting plesiomorphic and derived features. These authors did not have a complete skull that could provide evidence of a confluent external naris and antorbital fenestra, but this was suggested by the elongated and thin maxillary process of the jugal. With the description of Darwinopterus modularis by Lü et al. (2010), the existence of a non-pterodactyloid pterosaur with a nasoantorbital fenestra was confirmed.

The two new species described here - Kunpengopterus sinensis and Darwinopterus linglongtaensis - confirm several derived cranial traits in the non-pterodactyloid clade Wukongopteridae, such as the confluent naris and antorbital fenestra and the elongated maxillary process of the jugal. Furthermore, all members of this group show an inclined quadrate and a free nasal process (not united with the maxilla), also unknown in other non-pterodactyloids. The postcranial skeleton also shows some derived features such as elongated midcervical vertebrae. Another feature that seems to be derived is the reduction of the cervical ribs that is normally absent in derived pterosaurs except for the archaeopterodactyloid Gegepterus, in which short cervical ribs are reported (Wang et al. 2007).

Wukongopterids also show primitive features not only in the postcranial skeleton. The most conspicuous one is the rather short mandibular symphysis, even shorter than some non-pterodactyloids such as Dorygnathus and Rhamphorhynchus (e.g., Kellner 2003, Padian 2008a). Plesiomorphic postcranial features include the elongated tail enclosed by rod-like bony extensions of the zygapophyses and the relative lengths of the phalanges of the wing finger (see also Lü et al. 2010).

The relationship of the Wukongopteridae relative to the Pterodactyloidea is object of controversy. While in the phylogenetic analysis of Wang et al. (2009) this clade assumes a rather basal position, the study of Lü et al. (2010) has Darwinopterus closely related to the Pterodactyloidea. Although the phylogenetic position of the Wukongopteridae is not the main purpose of this paper, it should be noted that there are features for and against this relationship. The Wukongopteridae shares with the Pterodactyloidea relative to Rhamphorhynchus and Campylognathoides a nasoantorbital fenestra, a nasal process, elongated cervical vertebrae, and a comparatively larger wing metacarpal, even not really approaching the condition observed in basal pterodactyloids (e.g., the Archaeopterodactyloidea). Other features favor a closer relationship of the Rhamphorhynchidae (e.g., Rhamphorhynchus) to the Pterodactyloidea relative to the Wukongopteridae, such as an elongated mandibular symphysis, the diameter of the radius relative to the ulna and the proportions of the elements of the wing finger, with wukongopterids always showing the primitive condition (see Wang et al. 2009).

Another question is the phylogenetic relationship of Changchengopterus pani, described by Lü (2009) from a different locality of other wukongopterids, but regarded from the same deposits. The specimen represents a rather small long-tailed pterosaur with an estimated wing span of $475 \mathrm{~mm}$. Several unfused elements are observed, such as the extensor tendon process of the first phalanx of the wing finger, the elements of the proximal and distal carpal series, the scapula and coracoid, and the proximal tarsals and the tibia, indicating that this specimen represents a very young individual. 
Some of the posterior cervical vertebrae are preserved and, contrary to the original description, at least one is elongated. Based on the long tail, Lü (2009) referred this taxon to the Rhamphorhynchidae, which appears paraphyletic in his published analysis. Based on the slightly elongated cervical vertebra and the ratio of the wing finger phalanges (with the first one being the smallest), it is tentatively referred to the Wukongopteridae.

The two new species described here show that there is considerable morphological variation within the Wukongopteridae and further raise the question if both specimens attributed to Darwinopterus modularis represent the same taxon (see Kellner 2010 for a discussion on the problematic in recognizing pterosaur species). This is particularly of concern since the preparation of the referred (and more complete specimen) was not finished at the time of publication (Lü et al. 2010: Fig. 2f).

Among the most conspicuous differences within wukongopterids is the dentition. While the holotype of Darwinopterus modularis shows spike-like teeth (Lü et al. 2010, no information about the dentition of the referred specimen is available), Wukongopterus lii has cone-shaped and very pointed teeth. Darwinopterus linglongtaensis and Kunpengopterus sinensis also have short cone-shaped teeth, which are slightly blunter compared to the one of Wukongopterus. These differences suggest that these flying reptiles might have fed to some extent on different items, most likely insects or perhaps small fishes.

There is also significant variation in the feet within wukongopterids, particularly regarding the second phalanx of the fifth toe. Overall they are curved (boomerang-shaped), with the proximal region of this phalanx differing in proportion with the distal portion, changing from very short (Kunpengopterus sinensis) to very long (Wukongopterus lii) and with different angles relative to the distal portion (see diagnoses). Since this bone is regarded to be the main support of the uropatagium (e.g., Unwin and Bakhurina 1994, Kellner et al. 2010), it is entirely possible that these pterosaurs (and perhaps others) might have had uropatagia with different shapes and extension, analogous of the condition reported in bats. These variations in dentition and pedal morphology further suggest that these flying reptiles might have occupied slightly different ecological niches, a subject that deserves more research.

Lastly it should be noted that the new species described here solve a long debate regarding the position of the pteroid in the wrist. Against the proposals that this unique pterosaur bone was attached to the distal lateral carpal, either in the fovea carpalis (e.g., Wilkinson et al. 2006) or on the lateral side (Bennett 2007), this bone was attached to the proximal carpal series, as recently proposed by Peters (2009), and directed inward and not outward. It should be noted that, as observed by Bennett (2001) for the first time, there is a welldeveloped sesamoid inside the fovea carpalis. In Darwinopterus linglongtaensis there is another sesamoid positioned posteriorly to the pteroid and anteriorly to the proximal carpal series.

\section{CONCLUSION}

The new specimens described in this paper represent two distinct taxa named here Kunpengopterus sinensis and Darwinopterus linglongtaensis. They confirm the existence in the Wukongopteridae of plesiomorphic and derived traits in both skull and post cranial skeleton and not limited to only one part of them. The previously described Changchengopterus pani is based on a very young individual and is tentatively referred to the Wukongopteridae. Despite the discussion about the age and correct stratigraphic placement of the deposits in the Linglongta region, they have provided a large number of long-tailed pterosaurs that show more diversification than previously thought.

\section{ACKNOWLEDGMENTS}

We thank Yutong Li for preparing the specimens described here and Wei Gao for some of the photos that illustrate this article. Zhonghe Zhou (Institute of Vertebrate Paleontology and Paleoanthropology Chinese Academy of Sciences, China). Diogenes de Almeida Campos (Museu de Ciências da Terra, Rio de Janeiro), Juliana M. Sayão (Universidade Federal de Pernambuco, Vitória de Santo Antão) and Fabiana R.C. Nunes (Universidade Federal do Rio de Janeiro) are thanked for comments on the original version of this ms. This study was supported by the National Science Fund for Dis- 
tinguished Young Scholars (40825005), National Natural Science Foundation of China (40121202), The Major Basic Research Projects of the Ministry of Science and Technology of China (2006CB806400) - all to XW. AWAK acknowledges the Fundação Carlos Chagas Filho de Amparo à Pesquisa do Estado do Rio de Janeiro (FAPERJ no. E-26/102.779/2008) and the Conselho Nacional de Desenvolvimento Científico e Tecnológico (CNPq no. 307276/ 2009-0) for supporting research in China.

\section{RESUMO}

Dois novos pterossauros de cauda longa procedentes de Linglongta, Jianchang County da região oeste de Liaoning, China, são descritos e referidos ao clado Wukongopteridae. Kunpengopterus sinensis gen. et sp. nov. difere dos demais integrantes desse clado basicamente pela região mais arredondada da parte posterior do crânio, pelo espesso processo lacrimal do jugal e pela ausência de uma crista óssea premaxilar. Esta espécie apresenta uma crista formada por tecido mole acima da região frontal e possui o dedo alar proporcionalmente maior do que nos demais wukongopterídeos. A segunda espécie é referida ao gênero Darwinopterus, D. linglongtaensis sp. nov., com base na região posterior do crânio. Difere dos demais pterossauros wukongopterídeos por possuir o processo lacrimal do jugal delgado, o forâmen no processo nasal arredondado e pela condição menos curvada da segunda falange do quinto dígito do pé. As principais diferenças entre os Wukongopteridae são encontradas na dentição e nos pés, o que sugere que estes ocupavam nichos ecológicos ligeiramente distintos. O pterossauro de cauda longa Changchengopterus pani também é tentativamente referido a esse clado. Novas diagnoses para os wukongopterídeos Wukongopterus lii e Darwinopterus modularis são apresentadas.

Palavras-chave: Pterosauria, Wukongopteridae, Kunpengopterus, Darwinopterus, Liaoning, China.

\section{REFERENCES}

ANDRES B AND Ji Q. 2008. A new pterosaur from the Liaoning Province of China, the phylogeny of the pterodactyloidea, and convergence in their cervical vertebrae. Palaeontology 51: 453-469.

Bennett SC. 1993. The ontogeny of Pteranodon and other pterosaurs. Paleobiology 19: 92-106.
BEnnetT SC. 2001. The osteology and functional morphology of the Late Cretaceous pterosaur Pteranodon. Palaeontographica Abt A 260: 1-112.

BEnNetT SC. 2007. Articulation and function of the pteroid bone of pterosaurs. Jour Vert Paleont 27: 881-891.

Chang M, Chen PJ, WANG YQ AND WANG Y (Eds). 2003. The Jehol Biota. Shanghai Scientific \& Technical Publishers, Shanghai, 208 p.

Costa F And Kellner AWA. 2009. On two pterosaur humeri from the Tendaguru beds (Upper Jurassic, Tanzania). An Acad Bras Cienc 81: 813-818.

Dalla Vecchia FM. 2009. Anatomy and systematics of the pterosaur Carniadactylus gen. n. rosenfeldi (Dalla Vecchia, 1995). Riv Italiana Paleont Strati 115: 159-188.

Dalla Vecchia FM, Wild R, Hopf H and Reitner J. 2002. A crested rhamphorhynchoid pterosaur from the Late Triassic of Austria. Jour Vert Paleont 22: 196-199.

Frey E AND TISChlinger H. 2000. Weichteilanatomie der Flugsaurierfüsse und Bau der Scheitelkämme: Neue Pterosaurierfunde aus den Solnhofener Schichten (Bayern) und der Crato-Formation (Brasilien). Archaeopteryx 18: 1-16.

He HY, Wang XL, Zhou ZH, Zhu F, Jin F, WANG F, Ding X AND Boven A. 2004. ${ }^{40} \mathrm{Ar} /{ }^{39} \mathrm{Ar}$ dating of ignimbrite from Inner Mongolia, northeastern China, indicates a post-Middle Jurassic age for the overlying Daohugou Bed. Geophysical Res Letters 31: 1-4.

IBRAHIM N, UNWIN DM, MARTILL DM, BAIDDER L AND Zouhri S. 2010. A New Pterosaur (Pterodactyloidea: Azhdarchidae) from the Upper Cretaceous of Morocco. PLoS ONE 5(5): e10875. doi:10.1371/journal.pone.0010875.

Ji SA, Ji Q AND PADIAN K. 1999. Biostratigraphy of new pterosaurs from China. Nature 398: 573-574.

KELLNER AWA. 1996. Reinterpretation of a remarkably well preserved pterosaur soft tissue from the Early Cretaceous of Brazil. Jour Vert Paleont 16(4): 718-722.

Kellner AWA. 2003. Pterosaur phylogeny and comments on the evolutionary history of the group. In: BUFFETAUT E AND MAZIN J-M (Eds), Evolution and Palaeobiology of Pterosaurs. Geol Soc, London, Special Publications 217: 105-137.

KELlner AWA. 2004. The ankle structure of two pterodactyloid pterosaurs from the Santana Formation (Lower Cretaceous), Brazil. B Am Mus Nat Hist 285: 25-35.

Kellner AWA. 2010. Comments on the Pteranodontidae (Pterosauria, Pterodactyloidea) with the description of two new species. An Acad Bras Cienc 82: 1063-1084. 
Kellner AWA And CAmpos DA. 1999. Vertebrate Paleontology in Brazil - a review. Episodes 22: 238-251.

Kellner AWA, MAisey JG AND CAmpos DA. 1994. Fossil down feather from the Lower Cretaceous of Brazil. Paleontology 37: 489-492.

Kellner AWA, Wang X, Tischlinger H, CAmpos DA, Hone DWE And Meng X. 2010. The soft tissue of Jeholopterus (Pterosauria, Anurognathidae, Batrachognathinae) and the structure of the pterosaur wing membrane. Proc Royal Soc B 277: 321-329.

LÜ JC. 2009. A new non-pterodactyloid pterosaur from Qinglong County, Hebei Province of China. Acta Geol Sin 83: 189-199.

LÜ JC. 2010. A new boreopterid pterodactyloid pterosaur from the Early Cretaceous Yixian Formation of Liaoning Province, Northeastern China. Acta Geol Sin 84: 241246.

LÜ JC, Ji S, YUAN C And Ji Q. 2006. Pterosaurs from China. Beijing: Ed. Geological Publishing House, 147 p.

LÜ JC, UNWIN D, JIN X, LIU Y AND JI Q. 2010. Evidence for modular evolution in a long-tailed pterosaur with a pterodactyloid skull. Proc R Soc B 277: 383-389.

LÜ JC, Unwin DM, XU L and Zhang X. 2008. A new azhdarchoid pterosaur from the Lower Cretaceous of China and its implications for pterosaur phylogeny and evolution. Naturwissenschaften doi: 10.1007/s00114008-0397-5.

PADIAN K. 2008a. The Early Jurassic pterosaur Dorygnathus banthensis (Theodori 1830). Spec Pap Palaeont 80: 1-64.

PADIAN K. 2008b. The Early Jurassic pterosaur Campylognathoides Strand, 1928. Spec Pap Palaeont 80: 65-107.

Peters D. 2009. A reinterpretation of pteroid articulation in pterosaurs. Jour Vert Paleont 29: 1327-1330.

UNWIN DM. 2003. On the phylogeny and evolutionary history of pterosaurs. In: BuffetAut E AND MAZIN J-M (Eds), Evolution and Palaeobiology of Pterosaurs. Geol Soc, London, Special Publications 217: 139-190.

Unwin DM And BaKhURIna NN. 1994. Sordes pilosus and the nature of the pterosaur flight apparatus. Nature 371: 62-64.

UNWIN DM, LÜ J AND BAKHURINA NN. 2000. On the systematic and stratigraphic significance of pterosaurs from the Lower Cretaceous Yixian Formation (Jehol Group) of Liaoning, China. Mitt Mus Naturk Berlin, Geowiss R 3: 181-206.

Wang X, Kellner AWA, Jiang S and Meng X. 2009. An unusual long-tailed pterosaur with elongated neck from western Liaoning of China. An Acad Bras Cienc 81: 793-812.

Wang X, Kellner AWA, Zhou Z and Campos DA. 2005. Pterosaur diversity and faunal turnover in Cretaceous terrestrial ecosystems in China. Nature 437: 875879

Wang X, Kellner AWA, Zhou Z and Campos DA. 2007. A new pterosaur (Ctenochasmatidae, Archaeopterodactyloidea) from the Lower Cretaceous Yixian Formation of China. Cretac Res 28: 245-260.

Wang X, Kellner AWA, Zhou Z and Campos DA. 2008. Discovery of a rare arboreal forest-dwelling flying reptile (Pterosauria, Pterodactyloidea) from China. Proc Nat Acad Sci 105: 1983-1987.

WANG X AND ZHou ZH. 2006. Pterosaur assemblages of the Jehol Biota and their implication for the Early Cretaceous pterosaur radiation. Geol J 41: 405-418.

Wang X, Zhou Z, He H, Jin F, Wang Y, Zhang J, WANG Y, XU X AND ZHANG F. 2005. Stratigraphy and age of the Daohugou Bed in Ningcheng, Inner Mongolia. Chin Sci Bull 50: 2369-2376.

Wang X, Zhou Z, Zhang F And Xu X. 2002. A nearly completely articulated rhamphorhynchoid pterosaur with exceptionally well-preserved wing membranes and "hairs" from Inner Mongolia, northeast China. Chin Sci Bull 47: 226-230.

Wellnhofer P. 1975. Die Rhamphorhynchoidea (Pterosauria) der Oberjura Plattenkalke Süddeutschlands I: Allgemeine Skeltettmorphologie. Palaeontographica 148: $1-33$.

Wellnhofer P. 1978. Pterosauria. Handbuch der Palaeoherpetologie, Teil 19. Stuttgart: Gustav Fischer Verlag, Stuttgart, $82 \mathrm{p}$.

Wellnhofer P. 1991. The illustrated encyclopedia of pterosaurs. London: Salamander Books, 192 p.

WiLKINSON MT, UNWIN DM AND ELLINGTON CP. 2006. High lift function of the pteroid bone and forewing of pterosaurs. Proc R Soc B 273: 119-126.

ZHANG J. 2002. Discovery of Daohugou Biota (Pre-Jehol Biota) with a discussion on its geological age. J Stratigr 26: $173-177$.

Zhang H, Wang M And LiU X. 2008. Constrains on the upper boundary age of the Tiaojishan Formation volcanic rocks in West Liaoning-North Hebei by LA-ICP-MS dating. Chin Sci Bull 53: 3574-3584. 